\section{Reclamation of the Pontine Marshes}

IN the Engineer of May 11 and 18 is an illustrated account of the work being done in connexion with the reclamation of the famous Pontine Marshes in southern Italy. This work has been rendered possible by the passing by the Italian Government of the law of the 'Bonifica Integrale', commonly known as the Mussolini Law, 1928, which authorised the expenditure of 7,000 million lire $(£ 113,000,000)$ for works of public utility such as irrigation and water supply schemes, roads, and reclamation projects. "Among these great works of agricultural reconstruction," says the Engineer, "the reclamation of the Pontine Marshes deserves particular attention, not only on account of their geographical position almost at the doors of Rome (40 miles distant), and of their history, but above all from a technical point of view, as it is the first time in history that a similar vast enterprise has successfully been carried out, and that a flourishing town-Littoria-has, magiclike, risen within thirteen months from its inception on what were the pestilential malaria-stricken and deadly Pontine Marshes." The area of the marshes, across which once ran the Via Appia, is some 60,000 acres, and its reclamation had been discussed from the days of Caesar to Napoleon. But it remained a blot on the prestige of Italy. In 1926, however, a scientific survey of the district, its rainfall and geology, was carried out and each succeeding year has seen the construction of canals for drainage or irrigation, the erection of pumping and power stations, the clearing of woods, the breaking up of the soil and the settlement of some thousands of people on the recovered land. The colonisation of the area is being carried out by the Opera Nazionale Combettenti (National Ex-Service Men's Organisation) which provides each family of colonists with a house, live-stock and fodder, implements, seeds, etc., guarantees to pay for produce at market price and arranges easy terms of purchase. By October 1935 it is considered the scheme will see the colonisation of about 5,000 families, representing a population of 50,000 .

\section{River Water Survey}

THE forty-first annual report of the West Riding of Yorkshire Rivers Board for the year ended March 31 covers an extensive area, embracing, in part or in whole, the basins of the Lune, Ribble, Ure, Nidd, Wharfe, Aire, Calder, Don and Trent; therefore it naturally comprises a number of scientifically interesting, though miscellaneous, items of information, which cannot be effectively summarised within brief compass. As the twelve months in question coincided with the prevalence of the abnormally dry season which has made a shortage of water unpleasantly felt throughout Great Britain, it is not surprising to learn that "for extraordinarily lengthy periods the flow of the main rivers passing through the thickly populated manufacturing areas dwindled to about half the normal volume and a very large proportion of the water consisted of compensation water and effluents from sewage works and trade premises".
The Aire and the Calder, it is stated, continue to be the worst polluted streams in the West Riding, but the sources of pollution have become more and more localised as the work of the Board has proceeded. On the subject of excessive river pollution following sudden heavy downpours after long spells of dry weather, the explanation is put forward that during dry weather the whole flow of sewage can be fully treated at sewage works, and during continuously wet weather the dilution afforded by the streams is sufficient to obliterate the effects of the discharge of storm water sewage and surface water drainage, but that a heavy shower in dry weather may carry intense pollution into a depleted river. An analysis is given of a sample of river water from the Calder at time of maximum flow after heavy rainfall, demon. strating in a striking way the intensive wave of pollution set up under such conditions.

REFERENCE is made in the report to the important matter of river gauging, and it is stated that consistent attempts have been made to persuade local authorities to take a greater interest in the work and to co-operate in extending activities over a greater number of streams. It is satisfactory to find that these efforts have been attended by some degree of success, though the report adds: "it has required the rather alarming experiences of the droughts of 1929 and 1933 to make it evident that a comprehensive scheme of stream gauging is one of the essentials in regard to a systematic survey of the country's water resources". The action of the British Association in appointing a committee to investigate the question of an inland water survey is sympathetically alluded to, and it is stated that the Board has been asked by the Institution of Civil Engineers to co-operate in the movement by allowing its records of river gaugings to be made available for inclusion in a comprehensive survey which the Institution has in contemplation (see NaTuRE of Nov. 11, 1933, p. 725, and April 28, 1934, p. 625).

\section{Food Supply and Public Health}

IN his Chadwick Public Lecture delivered on May 29, Dr. John Boyd Orr discussed the national food supply and public health. He stated that, if necessary, Great Britain, which at present imports about half of its foodstuffs, could increase production sufficiently to become self-supporting. Between 1913 and 1928, the world's food production increased by 16 per cent, whereas the population of the world increased by only 10 per cent. But the amount of food a person can eat is limited, and in the case of some products, notably wheat, production has outrun consumption. In 1932 , the world's requirement in the international wheat market was 525 million bushels, whereas the exportable surplus of the great wheat-producing countries was 1,105 million bushels. The problem with regard to the supply of certain foodstuffs is now, not how to secure a sufficient supply, but rather how to dispose of the surplus, which is encumbering the world economic system. Governments are attempting, through international conferences, to evolve schemes to limit production. 